\title{
Article \\ Research on Homogeneous Charge Compression Ignition Combustion of Intake Port Exhaust Gas Recirculation Based on Cam Drive Hydraulic Variable Valve Actuation Mechanism
}

\author{
Linghai Han ${ }^{1}$, Jiaquan Duan ${ }^{1}$, Dingchao Qian ${ }^{1}$, Yanfeng Gong ${ }^{1}$, Yaodong Wang ${ }^{2, *}$, Fangxi Xie ${ }^{2}$ and Yan Su ${ }^{2}$ \\ 1 State Key Laboratory of Comprehensive Technology on Automobile Vibration and Noise \& Safety Control, \\ Changchun 130013, China; hanlinghai@faw.com.cn (L.H.); duanjiaquan@faw.com.cn (J.D.); \\ qiandingchao@faw.com.cn (D.Q.); gongyanfeng@faw.com.cn (Y.G.) \\ 2 State Key Laboratory of Automotive Simulation and Control, Jilin University, Changchun 130025, China; \\ xiefx2011@jlu.edu.cn (F.X.); suyan@jlu.edu.cn (Y.S.) \\ * Correspondence: yaodong20@mails.jlu.edu.cn
}

check for updates

Citation: Han, L.; Duan, J.; Qian, D.; Gong, Y.; Wang, Y.; Xie, F.; Su, Y. Research on Homogeneous Charge Compression Ignition Combustion of Intake Port Exhaust Gas

Recirculation Based on Cam Drive Hydraulic Variable Valve Actuation Mechanism. Energies 2022, 15, 438. https://doi.org/10.3390/en15020438

Academic Editor: Katarzyna Antosz

Received: 14 December 2021

Accepted: 4 January 2022

Published: 8 January 2022

Publisher's Note: MDPI stays neutral with regard to jurisdictional claims in published maps and institutional affiliations.

Copyright: (c) 2022 by the authors. Licensee MDPI, Basel, Switzerland. This article is an open access article distributed under the terms and conditions of the Creative Commons Attribution (CC BY) license (https:// creativecommons.org/licenses/by/ $4.0 /)$.

\begin{abstract}
The thermal efficiency of an efficient gasoline engine is only about $40 \%$ and it will produce a large number of harmful products. Curbing harmful emissions and enhancing thermal efficiency have always been the goals pursued and emission regulations are also being tightened gradually. As one of the main consumers of fossil fuels, automobile engines must further reduce fuel consumption and emissions to comply with the concept of low-carbon development, which will also help them compete with electric vehicles. Homogeneous charge compression ignition (HCCI) combustion combined with variable valve actuation (VVA) technology is one of the important ways to improve engine emissions and economy. HCCI combustion based on VVA can only be realized at small and medium loads. The actual application on the entire vehicle needs to be combined with spark ignition (SI) combustion to achieve full working condition coverage. Therefore, HCCI combustion needs fast valve response characteristics; however, the valve lift and timing of the existing VVA mechanisms are mostly controlled separately, resulting in poor valve response. In order to solve this problem, the cam driven hydraulic variable valve actuation ( $\mathrm{CDH}-\mathrm{VVA}$ ) mechanism was designed. The valve lift and timing can be adjusted at the same time and the switching of valve lift and timing can be completed in $1 \sim 2$ cycles. A set of combustion mode switching data is selected to show the response characteristics of the CDH-VVA mechanism. When switching from spark ignition (SI) to HCCI, it switches to HCCI combustion after only one combustion cycle and it switches to stable HCCI combustion after two combustion cycles, which proves the fast response characteristics of the CDH-VVA mechanism. At the same time, the CDH-VVA mechanism can form the intake port exhaust gas recirculation (EGR), as one type of internal EGR. This paper studies the HCCI combustion characteristics of the CDHVVA mechanism in order to optimize it in the future and enable it to realize more forms of HCCI combustion. At $1000 \mathrm{rpm}$, if the maximum lift of the exhaust valve (MLEV) is higher than $5.0 \mathrm{~mm}$ or lower than $1.5 \mathrm{~mm}, \mathrm{HCCI}$ combustion cannot operate stably, the range of excess air coefficient $(\lambda)$ is largest when the MLEV is $4.5 \mathrm{~mm}$, ranging from 1.0 1.5. Then, as the MLEV decreases, the range of $\lambda$ becomes smaller. When the MLEV drops to $1.5 \mathrm{~mm}$, the range of $\lambda$ shortens to 1.0 1.3. The maximum value of the MLEV remains the same at the three engine speeds (1000 rpm, $1200 \mathrm{rpm}$ and $1400 \mathrm{rpm}$ ), which is $5.0 \mathrm{~mm}$. The minimum value of the MLEV gradually climbs as the engine speed increase, $1000 \mathrm{rpm}: 1.5 \mathrm{~mm}, 1200 \mathrm{rpm}: 2.0 \mathrm{~mm}, 1400 \mathrm{rpm}$ : $3.0 \mathrm{~mm}$. With the increase of engine speed, the range of indicated mean effective pressure (IMEP) gradually declines, 3.53 6.31 bar (1000 rpm), 4.11 6.75 bar (1200 rpm), 5.02 6.09 bar (1400 rpm), which proves that the HCCI combustion loads of the intake port EGR are high and cannot be extended to low loads. The cyclic variation of HCCI combustion basically climbs with the decrease of the MLEV and slightly jumps with the increase of the engine speed. At $1000 \mathrm{rpm}$, when the MLEV is $5.0 \mathrm{~mm}$, the cyclic variation range is $0.94 \% \sim 1.5 \%$. As the MLEV drops to $1.5 \mathrm{~mm}$, the cyclic variation range rises to 3.5\% 4.5\%. Taking the maximum value of the MLEV as an example, the cyclic variation range of $1000 \mathrm{rpm}$ is $0.94 \% \sim 1.5 \%, 1200 \mathrm{rpm}$ becomes $1.5 \% \sim 2.3 \%$ and $1400 \mathrm{rpm}$ rises to $2.0 \% \sim 2.5 \%$.
\end{abstract}


Keywords: variable valve actuation; homogeneous charge compression ignition; exhaust gas recirculation; cyclic variation

\section{Introduction}

Automobile fuel consumption and emission regulations are becoming more and more strict. Major automotive markets require light-duty vehicles to expand fuel economy by $3 \sim 6 \%$ per year, and in the European Union, the target for carbon dioxide $\left(\mathrm{CO}_{2}\right)$ emissions from new cars in 2030 is to lessen $37.5 \%$, compared to $95 \mathrm{~g} / \mathrm{km}$ for passenger cars and $145 \mathrm{~g} / \mathrm{km}$ for light commercial vehicles in 2020 [1]. China National VI Phase B emission standards will be implemented in 2023, requiring lower emissions, further restricts the permissible amounts of total hydrocarbons (HC), non-methane hydrocarbon (NMHC) and nitrogen oxides (NOx) by more than 30\%, from 100, 68 and $60 \mathrm{mg} / \mathrm{km}$ to 50,35 and $25 \mathrm{mg} / \mathrm{km}$, respectively [2]. The thermal efficiency of an efficient gasoline engine is only about $40 \%$ and there is much room to ameliorate [3]. For automotive engines, as one of the main consumers of fossil fuels, while facing fierce competition from electric vehicles, must further decline fuel consumption and emissions. In recent years, variable compression ratio technology and more flexible variable valve actuation (VVA) technology have been gradually applied to automotive engines, such as Infiniti's variable compression ratio engine and Fiat's MultiAir VVA technology. The further optimization of VVA is conducive to engine performance and economy $[4,5]$.

The energy of fossil fuels is released through combustion. Therefore, more efficient combustion methods can also save energy and lessen emissions. Homogeneous charge compression ignition (HCCI) combustion has been proved to have high thermal efficiency and lower $\mathrm{NO}_{\mathrm{X}}$ and $\mathrm{CO}_{2}$ emissions at low and medium loads, which meets the development needs of the current energy society. The HCCI combustion research of gasoline engine originated from two-stroke engine. Onishi et al. [6] observed gasoline spontaneous combustion in a two-stroke engine, this combustion method is called active thermo-atmosphere combustion (ATAC). Gentili et al. [7] deeply studied the reasons why two-stroke gasoline engine can realize gasoline spontaneous combustion at low loads. The study found that the internal exhaust gas recirculation (EGR) is the way to realize gasoline self-ignition, the fresh mixture is heated by the hot exhaust gas and further pointed out that the temperature stratification between internal EGR and fresh mixture is the main reason for gasoline self-ignition. Compared with spark ignition (SI) combustion in two-stroke engine, HCCI combustion can reduce fuel consumption at low and medium loads [8,9]. Different from the four-stroke engine, the two-stroke engine is easier to trap a large amount of EGR in the cylinder, so the two-stroke engine can realize HCCI combustion without the help of other technologies. In the early stage, most of the methods such as intake air heating, external EGR coupled intake air heating and high compression ratio were used to study the HCCI combustion of the four-stroke gasoline engine. Gowthaman et al. [10] studied the influence of intake air temperature on HCCI combustion based on intake air heating, finding that the engine has better economy, power and emission characteristics at the inlet air temperature of $130^{\circ} \mathrm{C}$. Thring [11] studied the HCCI combustion using the external EGR coupled intake air heating in a single cylinder four-stroke engine and fuel compression spontaneous combustion was named HCCI combustion for the first time in this paper. The paper pointed out that under proper conditions, the fuel economy of HCCI combustion can be compared with direct injection diesel engine. Christensen et al. [12] used variable compression ratio and intake air heating technologies to study the HCCI combustion characteristics of n-heptane, isooctane, gasoline, alcohol and natural gas. The research results showed that under the condition of not requiring intake air heating, $\mathrm{n}$-heptane, isooctane and gasoline (98 RON) require engine compression ratio of $11,21.5$ and 22.5; when the compression ratio is 21 , ethanol and natural gas require $80^{\circ} \mathrm{C}$ and $120^{\circ} \mathrm{C}$ for the heating temperature of the intake air. Intake air heating requires additional heat source and its own thermal inertia, which is 
difficult to accurately control and apply on a large scale. The high compression ratio can realize HCCI combustion, but it cannot cover all working conditions. If it is to be applied in practice, it needs to be combined with variable compression ratio technology, but its implementation is complicated and difficult to apply in practice. After a lot of research, the HCCI combustion of the internal EGR is realized based on VVA. The exhaust valve closes early and the exhaust valve lift drops to increase the EGR in the cylinder and the fresh gas mixture is heated by the high temperature exhaust gas. The heated fresh air mixture reaches the self-ignition state at the end of compression, thus forming HCCI combustion. Willand et al. [13] used the method of negative valve overlap angle to achieve HCCI combustion for the first time. By reducing the valve opening duration, more than $40 \%$ of the residual exhaust gas is retained and HCCI combustion is achieved. Kontarakis et al. [14] found that the range of HCCI combustion is low to medium speed and low to medium loads; HCCI combustion has low NOx emission and slightly higher HC emission; HCCI combustion has a relatively narrow sensitivity range to changes in air-fuel ratio; HCCI combustion speed is fast and the combustion duration is basically unchanged when the excess air coefficient $(\lambda)$ is equal to 1. Li et al. [15] studied HCCI Combustion based on VVA technology and found that the fuel consumption of HCCI combustion is reduced by more than $5 \sim 30 \%$. The load range of HCCI combustion can be expanded by spark ignition assisted combustion $[16,17]$ and external EGR [18].

HCCI combustion based on VVA can only be realized at small and medium loads. The actual application on the entire vehicle needs to be combined with SI combustion to achieve full working condition coverage. Therefore, the smooth switching of SI and HCCI combustion is the focus of attention. The smoothness of mode switching is affected by the following two points, the characteristics of the VVA mechanism (valve lift and timing switching mode) and the transient control strategy. Among them, the transient control strategy needs to fully consider the characteristics of the VVA mechanism. As a mature solution, VVA has been widely used in SI engine. The application of VVA technology in SI engine is to enhance the charging efficiency of the engine at different speeds and obtain better performance. The response speed of SI engine to VVA mechanism is much lower than that of HCCI engine. When the response speed of the VVA mechanism is poor, the HCCI combustion is easy to misfire or knock. At present, most of the VVA mechanisms that realize HCCI combustion are refitted from SI engine VVA mechanisms, the timing and lift of the VVA mechanism are mostly controlled separately. The valve timing is continuously variable by solenoid valve and hydraulic oil [19-22]. The valve lift is divided into two-stage type $[20,23]$ and fully variable type $[19,21,22]$, which is controlled by solenoid valve [20], solenoid valve coupling hydraulic oil [22] or stepping motor $[19,21]$. The method of adjusting valve lift and timing separately results in poor valve response, the intermediate process of combustion mode switching is still more than five cycles after optimization [21]. In the literature [19], there are even more than 10 cycles; it is precisely because of the slow valve response speed that the excessive mode is designed, which increases the difficulty of control and the time for mode conversion. When the combustion mode is switched, the valve lift and timing need to be able to respond quickly and accurately, which is a test for VVA mechanism design. Recent research on HCCI combustion mainly focuses on alternative fuels, numerical simulation, control strategies and load expansion. Calam et al. [24] analyzed engine performance and emission characteristics of ethanol, methanol, fusel oil, butanol, isopropanol and naphtha with n-heptane blends on HCCI engine, found that the start timing of combustion and combustion duration of HCCI combustion can be controlled by using alternative fuels. Verma et al. [25] studied the performance characteristics of HCCI engine for various fuels and additives. The research shows that the HCCI engine is about $20 \%$ more efficient than the traditional SI and Compression ignition (CI) engine; the thermal efficiency of natural gas is about $10 \%$ higher than that of diesel and $5 \sim 10 \%$ higher than that of gasoline in the HCCI engine. Asghari et al. [26] developed a new numerical model to predict the knocking combustion in HCCI engines. D'Amato et al. [27] simulated the relationship between turbulence, combustion chamber structure and swirl motion and 
found that the swirl motion can dissipate turbulence, which promotes combustion; the flat-piston geometry burn faster than the cup-in-piston geometry and emit fewer emissions. Zhou et al. [28] fully considered the characteristics of HCCI combustion, namely, lean burn and high EGR rate and developed HCCI combustion models for ethanol, natural gas and primary reference fuel blends. Hikita et al. [29] built a model-based feedforward controller, generated the target Gross IMEP cycle by cycle, which was impossible with a map-based control constructed by steady state operation experiments and realized the stable HCCI combustion. Nam et al. [30] proposed a novel modeling, estimation and control framework for HCCI engines by utilizing cylinder pressure sensor. This framework can cover the wide combustion spectrum of HCCI engines, including partial combustion and misfire and can also achieve more stable and precise transient control. Zhu et al. [31] used pressure sensor and ion current sensor dropped the recognition error of incomplete combustion and expanded HCCI combustion range based on water injection.

Through a large number of studies, HCCI combustion based on VVA mechanism has been a mature combustion mode, but there are relatively few studies dedicated to promoting the response characteristics of VVA mechanism for HCCI combustion. Regarding the issue above, the cam driven hydraulic variable valve actuation (CDH-VVA) mechanism was developed; the valve opening time is unchanged and the valve lift and closing time can be adjusted at the same time; the lift is continuously adjustable from 0 to the maximum [32]. The CDH-VVA mechanism can complete the switching of valve lift and timing in 1 2 cycles, which can better meet the requirement of HCCI combustion for valve response. This paper studies the switching process of SI combustion and HCCI combustion and demonstrates the response characteristics of the CDH-VVA mechanism. HCCI combustion can be realized in the following ways based on VVA mechanism: combustion chamber EGR, early exhaust port EGR, parallel exhaust port EGR, late exhaust port EGR and intake port EGR [33]. The range of HCCI combustion in different EGR forms is different. The CDH-VVA mechanism can form intake port EGR. Another purpose of this paper is to study the HCCI combustion range of the intake port EGR, which is rarely studied, in order to optimize the CDH-VVA to research the HCCI combustion of other internal EGR. At three selected engine speeds (1000 rpm, $1200 \mathrm{rpm}$ and $1400 \mathrm{rpm}$ ), the exhaust valve lift range of HCCI combustion is studied. At each exhaust valve lift curve, the paper studies the $\lambda$ range and cycle variation. Finally, the indicated mean effective pressure (IMEP) range of the CDH-VVA engine is acquired. A set of combustion mode switching data is selected to prove the fast response characteristics of the CDH-VVA mechanism.

\section{Experimental Setup and Methods}

\subsection{Experimental Setup}

The experimental engine is refitted from a single cylinder four stroke direct injection diesel engine and the parameters are shown in Table 1. Adopt intake port injection and install spark plug with miniature pressure sensor in the fuel injector of the original diesel engine. Install an air throttle in the intake port to control the engine intake.

Table 1. The diesel engine parameters.

\begin{tabular}{cc}
\hline Engine Properties & Specifications \\
\hline Engine type & Single/Horizontal \\
Combustion chamber type & $\omega$ \\
Bore/Stroke & $80 \mathrm{~mm} / 80 \mathrm{~mm}$ \\
Connecting rod length & $130 \mathrm{~mm}$ \\
Displacement & $0.402 \mathrm{~L}$ \\
Rated speed & $2600 \mathrm{rpm}$ \\
Rated power & $5.67 \mathrm{~kW}$ \\
Compression ratio & $17.5: 1$ \\
Intake valve number & 1 \\
Exhaust valve number & 1 \\
\hline
\end{tabular}


The intake and exhaust valve of the engine are controlled by the CDH-VVA. Figure 1 shows the working principle of CDH-VVA, which consists of a tappet piston group (TPG) and a valve piston group (VPG). A constant low-pressure (5 bar) hydraulic oil source is provided by the external hydraulic oil system. The hydraulic oil flow returning to the external hydraulic oil system through the oil return port is controlled by the rotation angle of throttle valve. The high-low check valve (HLCV) prevents the hydraulic oil from returning to the external hydraulic oil system through the oil inlet port. The engine camshaft is driven by the crankshaft and the tappet piston (TP) is driven by the cam rotation. When the TP moves upward following the rotation of the cam, the pressure in the tappet piston cavity (TPC) gradually increases. The high-pressure oil overcomes the spring preload of the one-way restrictor valve (OWRV) and enters the valve piston cavity (VPC). Then, the high-pressure oil can also enter the VPC through the bypass hole. The high-pressure oil overcomes the valve spring preload (VSP) and pushes the engine valve to open. When the $\mathrm{TP}$ is driven downward by the rotation of the cam, the VPC pressure begins to decrease. The engine valve starts to return, the hydraulic oil returns to the TPC through the bypass hole and the thin-walled hole. The diameter of the bypass hole is larger than the thin-walled hole, which can make the valve fall quickly when the valve falls and valve-seating buffer mechanism (VSBM) serves as a seat cushion at the end of valve closing.

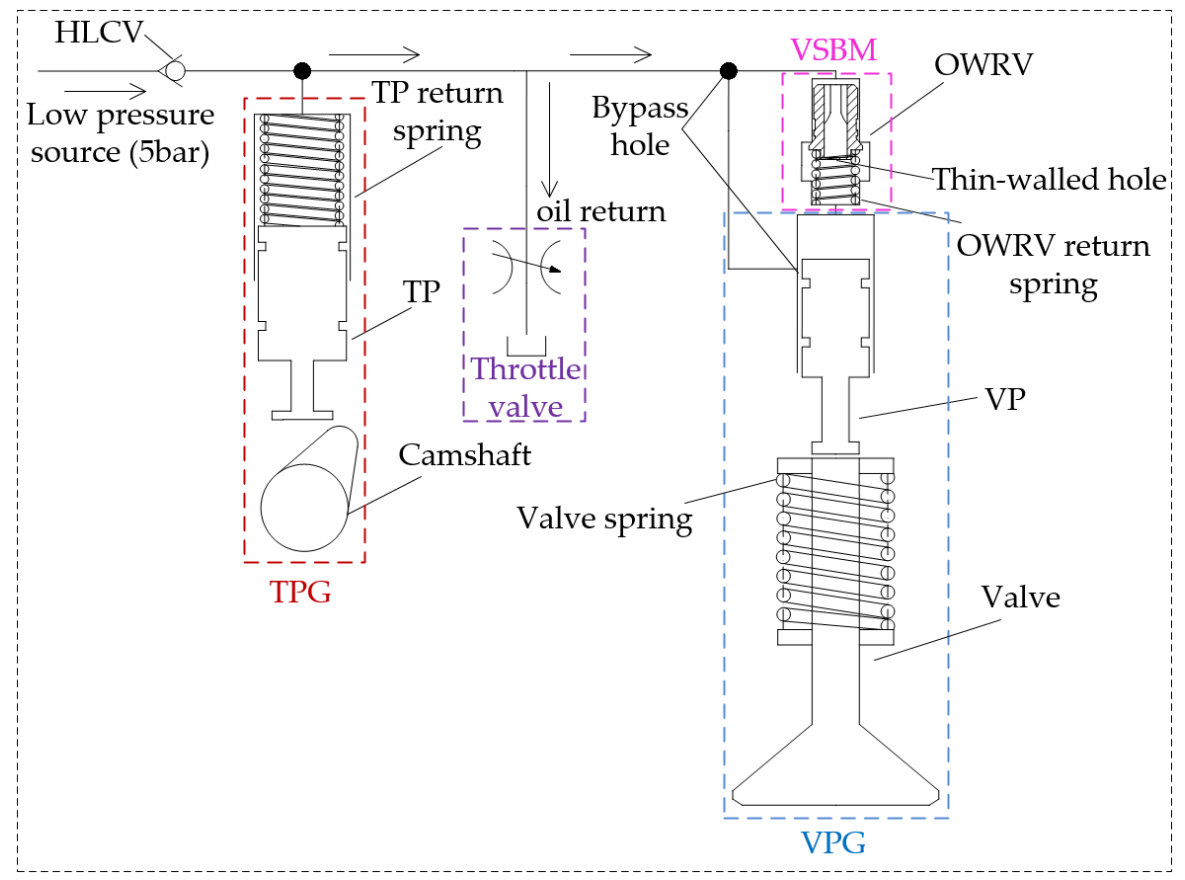

Figure 1. The working principle of CDH-VVA.

By adjusting the throttle valve to change the effective flow area, the continuous variable valve lift is realized. In this paper, the intake and exhaust valve lift are adjusted by the throttle valves rotation angle (ITVRA, intake throttle valve rotation angle; ETVRA, exhaust throttle valve rotation angle), which are controlled by the stepping motors. When the throttle valve rotates counterclockwise, the effective section of the oil return increases and the maximum lift of the engine valve falls; when the throttle valve rotates clockwise, the effective section of the oil return declines and the maximum lift of the engine valve rises. Figure 2 shows the lift curves of the intake and exhaust valve of the modified engine. 


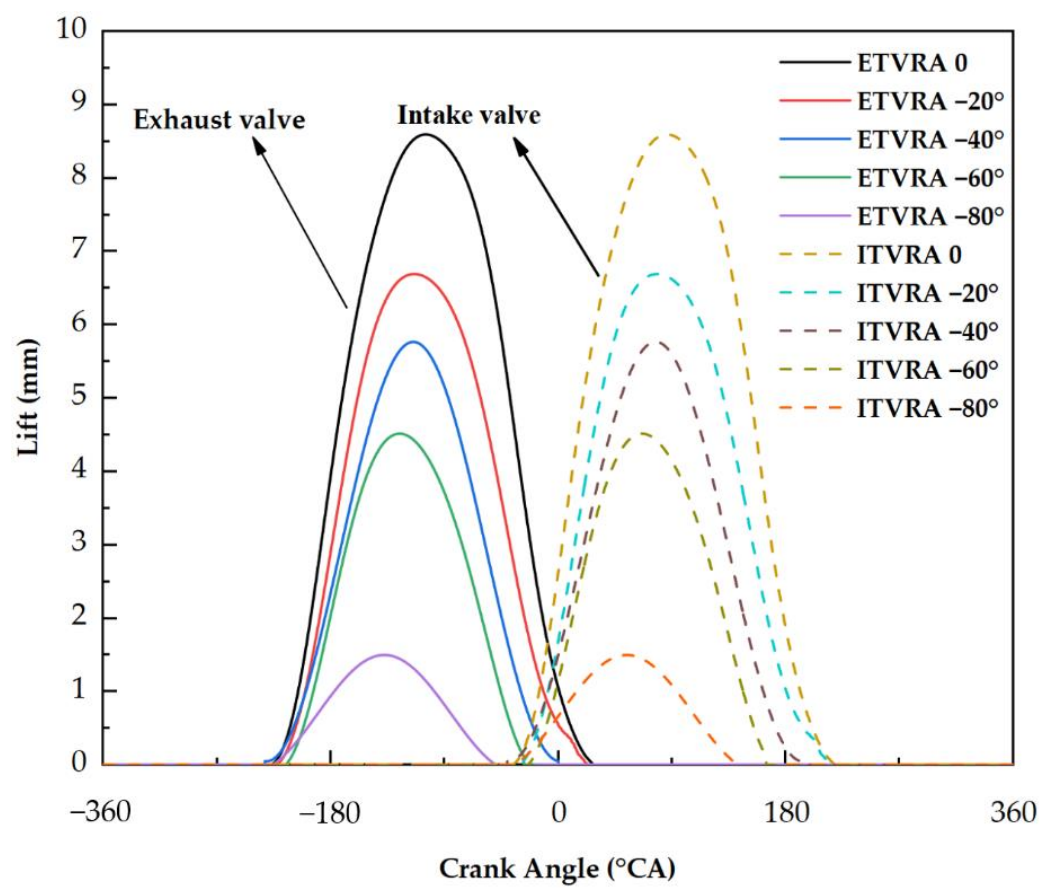

Figure 2. Engine valves lift curves (negative sign indicates counterclockwise rotation).

The fuel consumption meter is DF-2420 from ONO SOKKI, Japan. The angle scale type is Kistler 2613B and the spark plug with miniature pressure sensor is Kistler 6115B. The Lambda analyzer is ETAS LA4, the engine ECU model is Haltech sprint 500 and the combustion analyzer is AVL IndiMicro 602. The type of the two stepping motors is SUMTOR (Wuxi, China) 42HS4013A4 and the stepping motor driver is SUMTOR DM430.

\subsection{Experimental Methods}

During the experiment, the fuel is RON 95 gasoline, the injection method is intake port injection and the injection pressure is 4 bar. The intake air temperature is $30{ }^{\circ} \mathrm{C}$ and the cooling water temperature is $80^{\circ} \mathrm{C}$. The air throttle valve is kept fully open.

Steady State Experiment: three engine speeds are selected, $1000 \mathrm{rpm}, 1200 \mathrm{rpm}$ and $1400 \mathrm{rpm}$. The intake valve lift maintains the maximum and the exhaust valve is gradually closed early. The HCCI combustion range under different exhaust valve lifts is studied. Under the same exhaust valve lift, the fuel injection quantity is adjusted to find HCCI lean combustion limit, $\lambda$ is not less than 1 .

Experiment of Switching from SI Mode to HCCI Mode: it is relatively difficult to switch from SI to HCCI and switching from HCCI to SI is relatively simple [34], so the focus is on the characteristics of the CDH-VVA engine switching from SI to HCCI. The engine speed is $1000 \mathrm{rpm}$, equal oil volume and $\lambda(\lambda=1.2)$ switching. The IMEP of SI combustion (Maximum lift of the intake valve is $4.5 \mathrm{~mm}$, ITVRA $=-60^{\circ}$; maximum lift of the exhaust valve is $8.6 \mathrm{~mm}, \mathrm{ETVRA}=0$ ) is $6.7 \mathrm{bar}$, switching to HCCI combustion (Maximum lift of the intake valve is $8.6 \mathrm{~mm}$, ITVRA $=0$; maximum lift of the exhaust valve is $5 \mathrm{~mm}$, ETVRA $=-50^{\circ}$ ), as shown in Figure 3. 


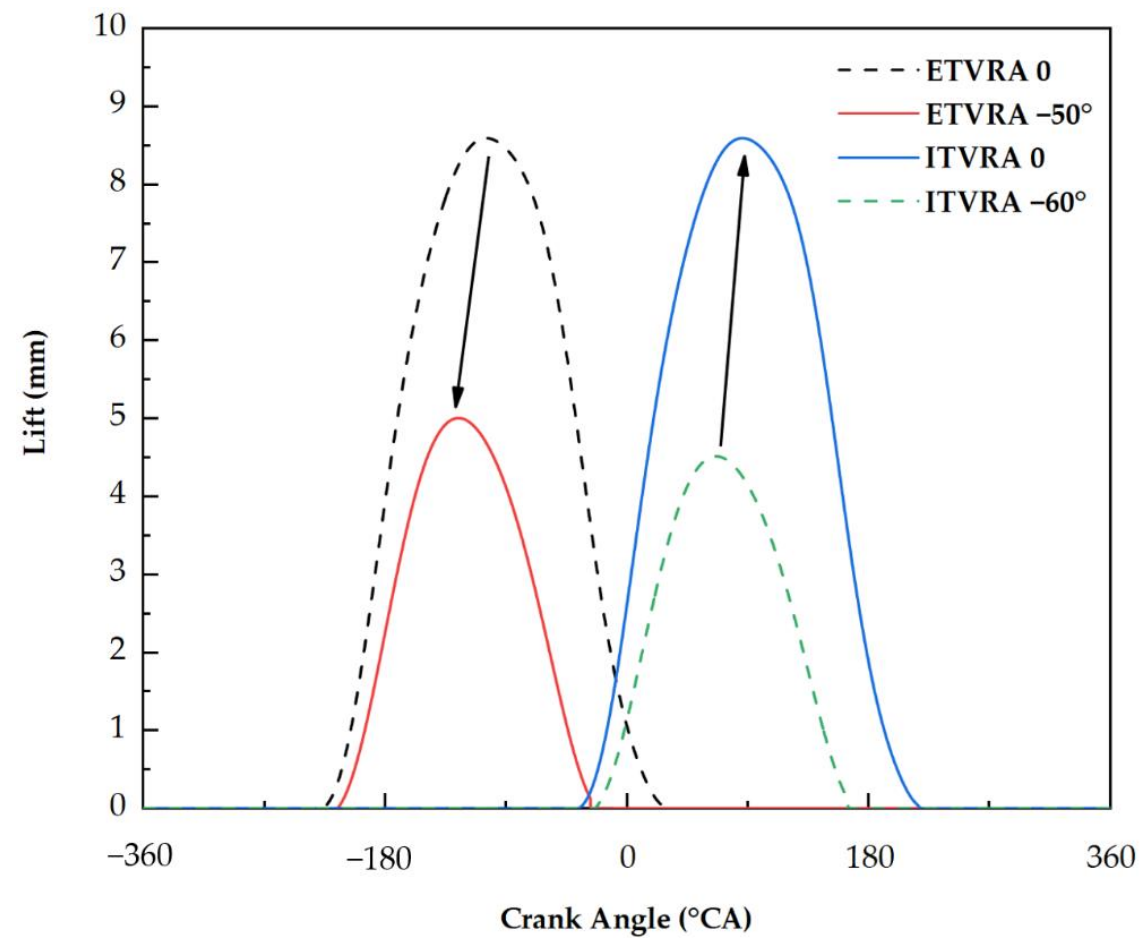

Figure 3. Exhaust and intake valve lift curves of SI and HCCI.

\section{Results and Discussions}

\subsection{Steady State Experimental Results}

As shown in Figure 4, when the engine speed is $1000 \mathrm{rpm}$, if the maximum lift of the exhaust valve (MLEV) is higher than $5.0 \mathrm{~mm}$ or lower than $1.5 \mathrm{~mm}$, HCCI combustion cannot be realized. When the MLEV is higher than $5.0 \mathrm{~mm}$, there is not enough hightemperature EGR to heat the fresh mixture, which makes it impossible to achieve HCCI combustion; when the MLEV is lower than $1.5 \mathrm{~mm}$, the amount of EGR in the cylinder is too large, resulting in the inability to maintain stable HCCI combustion. When the MLEV is $4.5 \mathrm{~mm}$, the range of $\lambda$ is the largest (1 1.5) and then as the MLEV falls, the range of $\lambda$ becomes smaller and the residual exhaust gas entering the intake port is added. The residual exhaust gas and the combustible mixture are more fully mixed and the temperature loss rises. After the MLEV is reduced, although the amount of EGR in the cylinder rises, but the temperature of the EGR is greatly lost and cannot heat more fresh air. Therefore, as the MLEV drops, the range of $\lambda$ is smaller. As the engine speed increases, the minimum value of MLEV gradually climbs. When the engine speed is $1000 \mathrm{rpm}$, the minimum value of the MLEV is $1.5 \mathrm{~mm}$ and at $1400 \mathrm{rpm}$, the minimum value of the MLEV is jumped to $3 \mathrm{~mm}$. When the engine speed increases, the gas exchange time decreases and the exhaust gas entering the intake port has an enhanced inhibitory effect on the engine's intake of fresh air. If the MLEV is too low, the engine cannot operate stably. Therefore, when the engine speed increases, the minimum value of the MLEV climbs accordingly. 


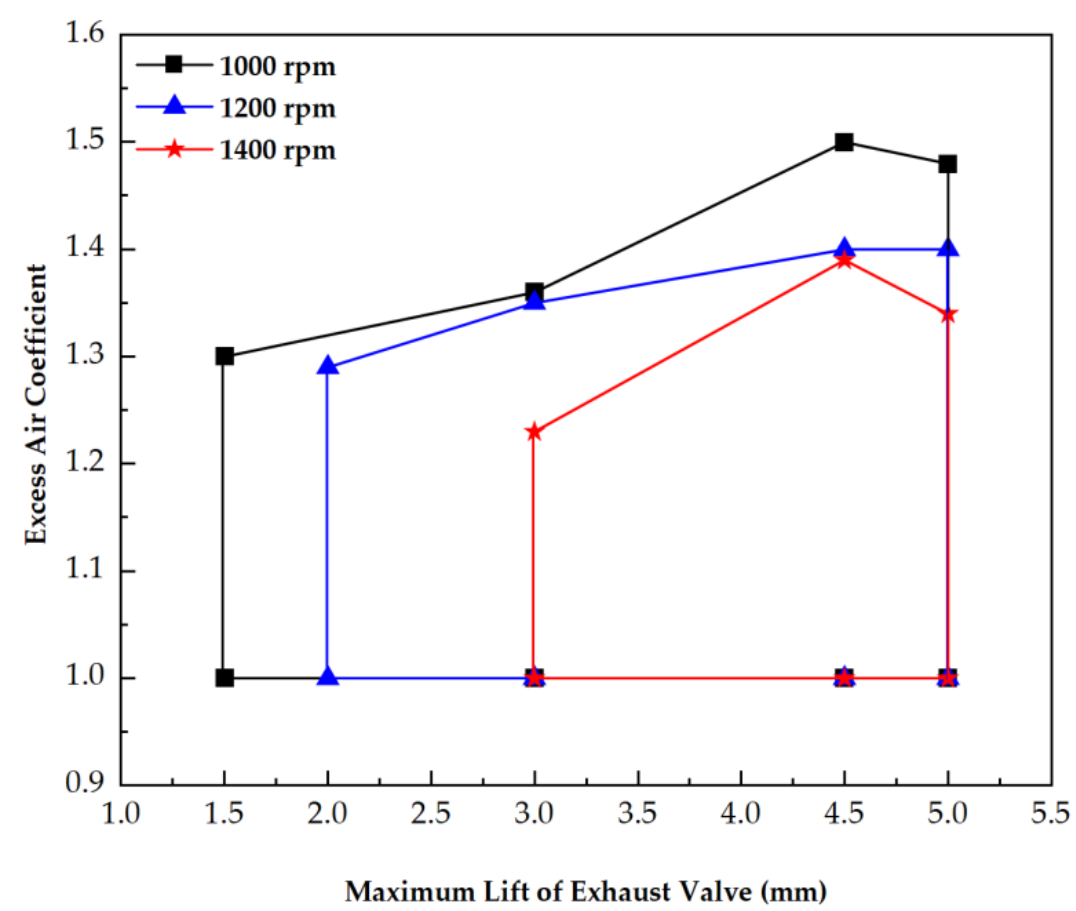

Figure 4. The range of $\lambda$ under different exhaust valve lifts at $1000 \mathrm{rpm}, 1200 \mathrm{rpm}$ and $1400 \mathrm{rpm}$.

Figure 5 shows the IMEP range under different exhaust valve lifts at $1000 \mathrm{rpm}$. The range of IMEP narrows from 4.67 6.31 bar to 3.53 4.38 bar with the MLEV drops. As the MLEV drops, the in-cylinder EGR rate gradually expands and the combustible mixture gradually lessens. IMEP ${ }_{\text {Max }}$ at $\lambda=1$ gradually declines. IMEP ${ }_{\text {Min }}$ is determined by the maximum dilution under the specified exhaust valve lift.

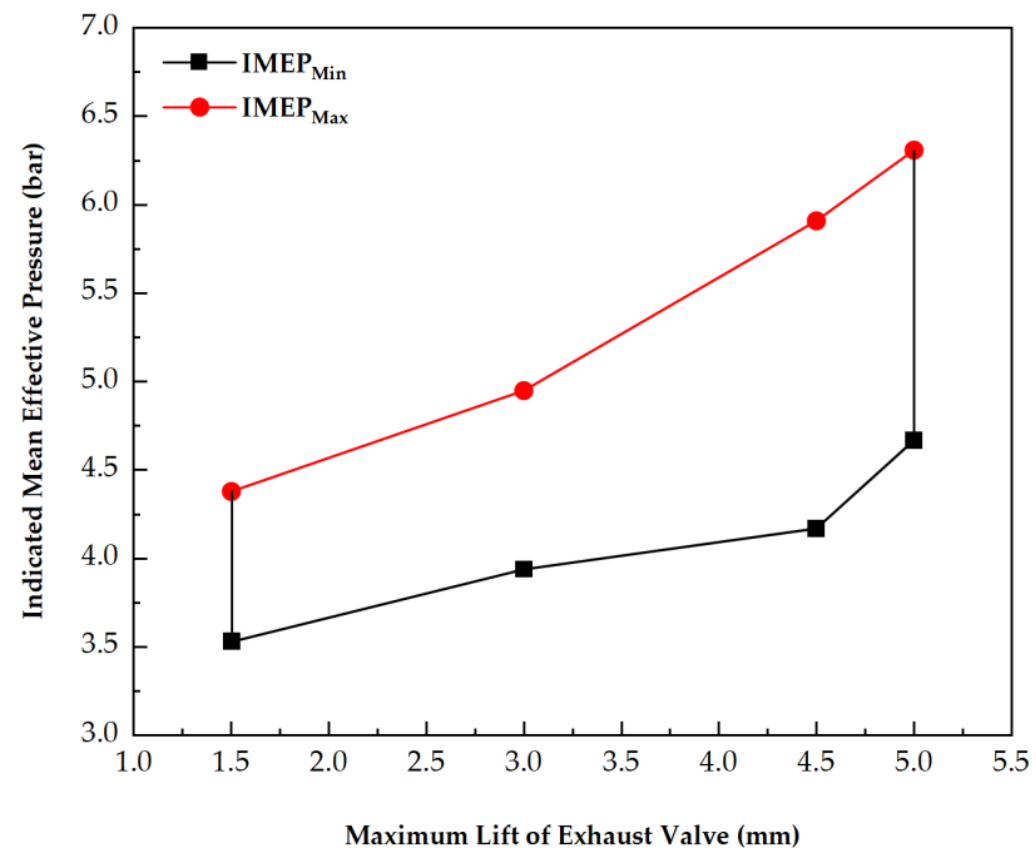

Figure 5. The range of IMEP under different exhaust valve lifts at $1000 \mathrm{rpm}$.

As shown in Figure 6, as the engine speed increases, the range of IMEP gradually shortens, 1000 rpm: 3.53 6.31 bar; $1200 \mathrm{rpm}$ : 4.11 6.75 bar; $1400 \mathrm{rpm}$ : 5.02 6.09 bar, which is consistent with the change law of $\lambda$ with engine speed. 


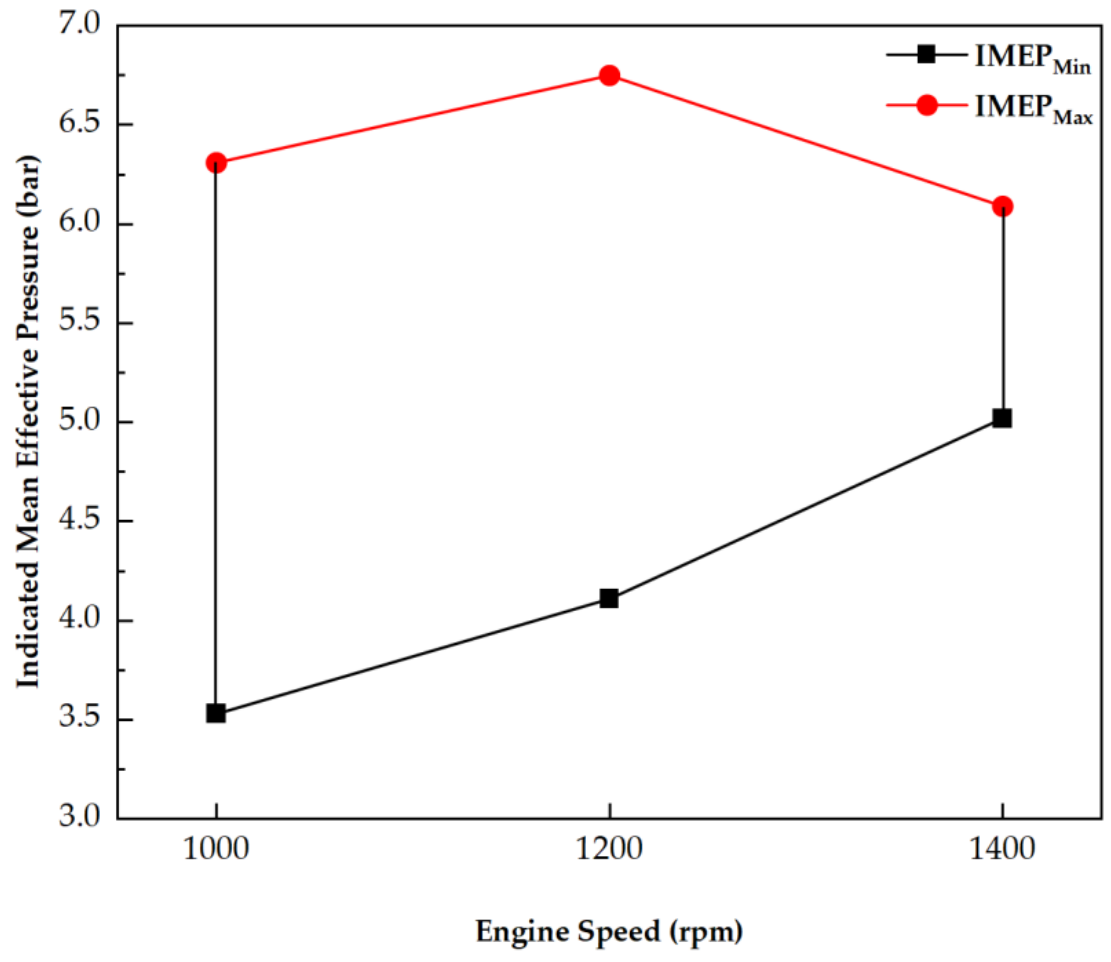

Figure 6. The range of IMEP at $1000 \mathrm{rpm}, 1200 \mathrm{rpm}$ and $1400 \mathrm{rpm}$.

Figures 7-9 are the cyclic variation of HCCI combustion at different exhaust valve lifts at $1000 \mathrm{rpm}, 1200 \mathrm{rpm}$ and $1400 \mathrm{rpm}$. The cyclic variation of HCCI combustion basically climbs with the decrease of the MLEV. It is observed during the experiment that once the $\lambda$ is greater than a certain value, the HCCI combustion will suddenly change from stable combustion to misfire. There is almost no intermediate process, that is, the combustion cycle with large cyclic variation but no misfire. The cyclic variation of HCCI combustion jumps slightly with the increase of engine speed.

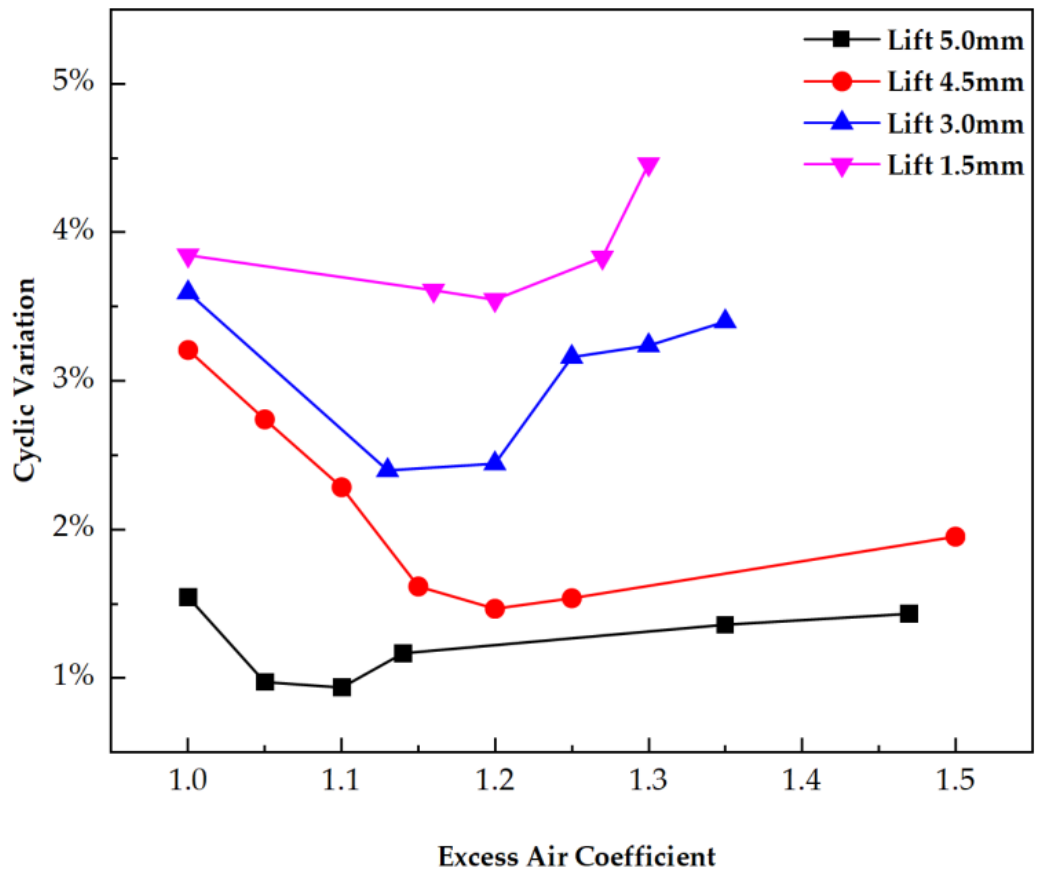

Figure 7. The cyclic variation of HCCI combustion under different exhaust valve lifts at $1000 \mathrm{rpm}$. 


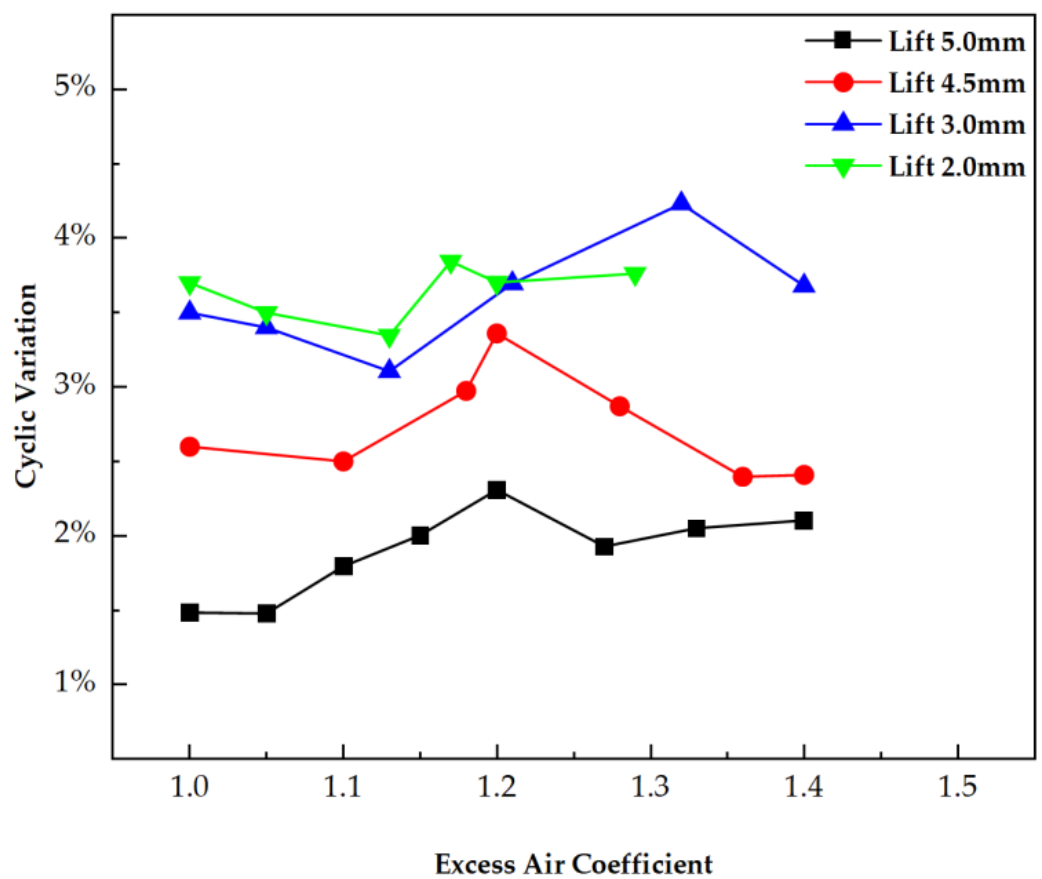

Figure 8. The cyclic variation of HCCI combustion under different exhaust valve lifts at $1200 \mathrm{rpm}$.

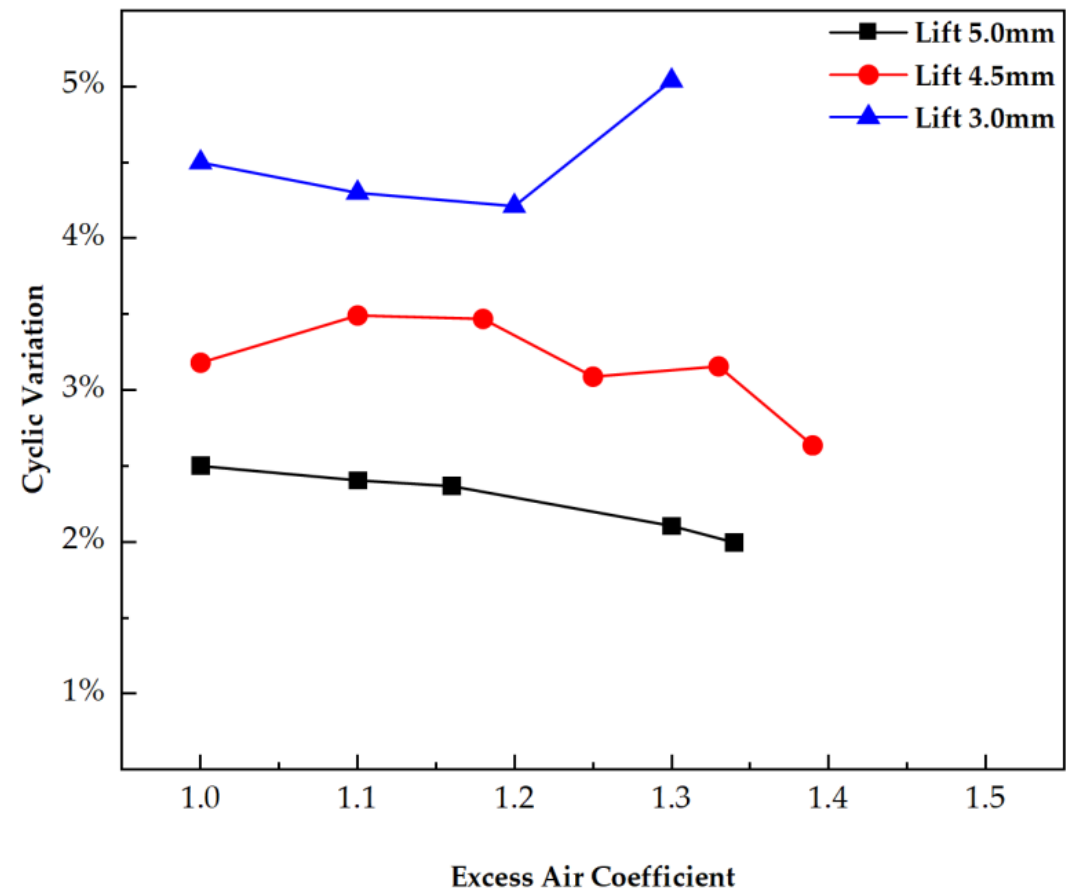

Figure 9. The cyclic variation of HCCI combustion under different exhaust valve lifts at $1400 \mathrm{rpm}$.

The effects of EGR on HCCI combustion mainly include the following points [35] Charge heating effect-the high-temperature residual exhaust gas heats the combustible mixture, which can advance the self-ignition time of the combustible mixture and shorten the combustion duration; dilution effect-reducing the oxygen concentration and chemical reaction rate and prolonging the combustion duration; heat capacity effect-the specific heat of the exhaust gas is relatively high, which will reduce the heat release rate and prolong the combustion duration; chemical effect-chemical reactions involving $\mathrm{CO}_{2}$ and $\mathrm{H}_{2} \mathrm{O}$ in the burned gases; stratification effect—-there is a high temperature zone in the boundary 
area between hot exhaust gas and combustible mixture, which promotes HCCI combustion. During the experiment, the intake valve maintains the maximum lift (ITVRA $=0)$, the exhaust valve gradually closes early and the MLEV gradually falls. Figure 10 shows the cylinder pressure curves of intake port EGR type HCCI combustion at $1000 \mathrm{rpm}$. The second peak of the cylinder pressure curves does not exceed 7 bar and appears before the top dead center of exhaust. Since the opening time of the intake valve is $36{ }^{\circ} \mathrm{CA}$ BTDC, part of the exhaust gas will enter the intake port and mix with the combustible mixture and then be sucked into the cylinder again after the piston goes down and the cylinder pressure is lower than the inlet pressure, so as to form intake port EGR. The second peak of cylinder pressure is symmetrical about the top dead center, which is the HCCI combustion of the combustion chamber EGR (the exhaust valve early closing angle and the intake valve late opening angle are equal) [14,36]. Residual exhaust gas does not leave the cylinder; the temperature loss is small and forms obvious stratification with the fresh mixture, which is the easiest to achieve HCCI combustion. However, the temperature loss of the intake port EGR is very large and the stratification of the residual exhaust gas and combustible mixture is weakened, which is not conducive to HCCI combustion. The greater the early closing angle of the exhaust valve, the more exhaust gas entering the intake port, although the amount of EGR in the cylinder increases but the temperature decreases, the engine pumping loss is also greater.

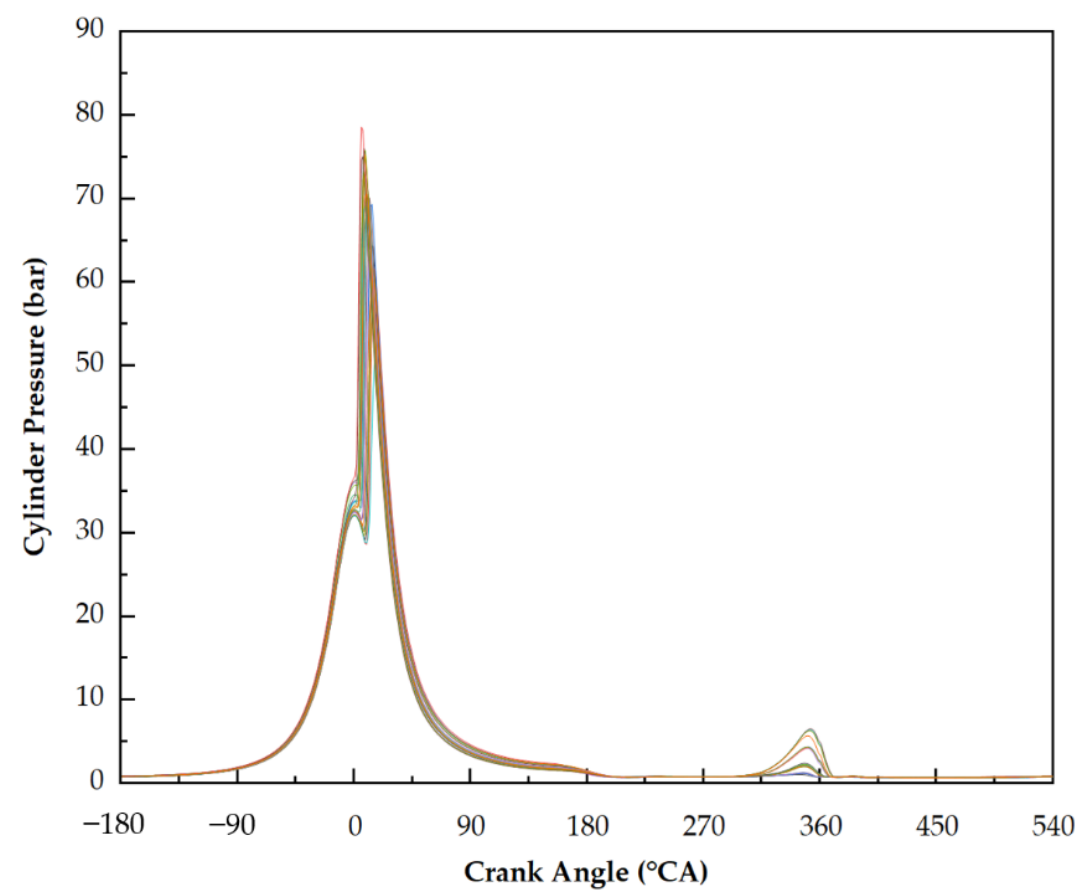

Figure 10. The cylinder pressure curves of intake port EGR type HCCI combustion at $1000 \mathrm{rpm}$.

\subsection{Switching from SI to HCCI}

As shown in Figure 11, when switching from SI to HCCI, only one intermediate cycle (the 7th cycle) is experienced. Cycles 1 7 are SI combustion and HCCI combustion starts from cycle 8 . The cylinder pressure of the first HCCI combustion cycle rises rapidly and the peak cylinder pressure of the second HCCI combustion cycle (the 9th cycle) has returned to a stable value. As shown in Figure 12, the pressure rise rate of HCCI combustion exceeds $20 \mathrm{bar} /{ }^{\circ} \mathrm{CA}$, which is much higher than the $10 \mathrm{bar} /{ }^{\circ} \mathrm{CA}$ of SI combustion. It can be seen from Figure 13 that the ignition time of the first HCCI cycle is greatly advanced, bringing the CA50 close to the compression top dead center, resulting in the highest rate of pressure rise. This is mainly due to the higher temperature in the SI combustion and the higher exhaust temperature, leading to the temperature of the residual exhaust gas in the early HCCI cycle is higher; the heating effect on the mixture is more obvious. From the combustion point of 
view, after switching from SI to HCCI and going through two combustion cycles (cycle 7 and cycle 8), stable HCCI combustion is obtained. The duration of HCCI combustion is only $2 \sim 3{ }^{\circ} \mathrm{CA}$. The combustion stability of HCCI combustion is better than SI combustion. Since the $\mathrm{HCCI}$ combustion center of gravity is closer to the compression top dead center, the negative compression work rises, causing the average IMEP of HCCI combustion (6.2 bar) to be lower than the average IMEP of SI combustion (6.7 bar).

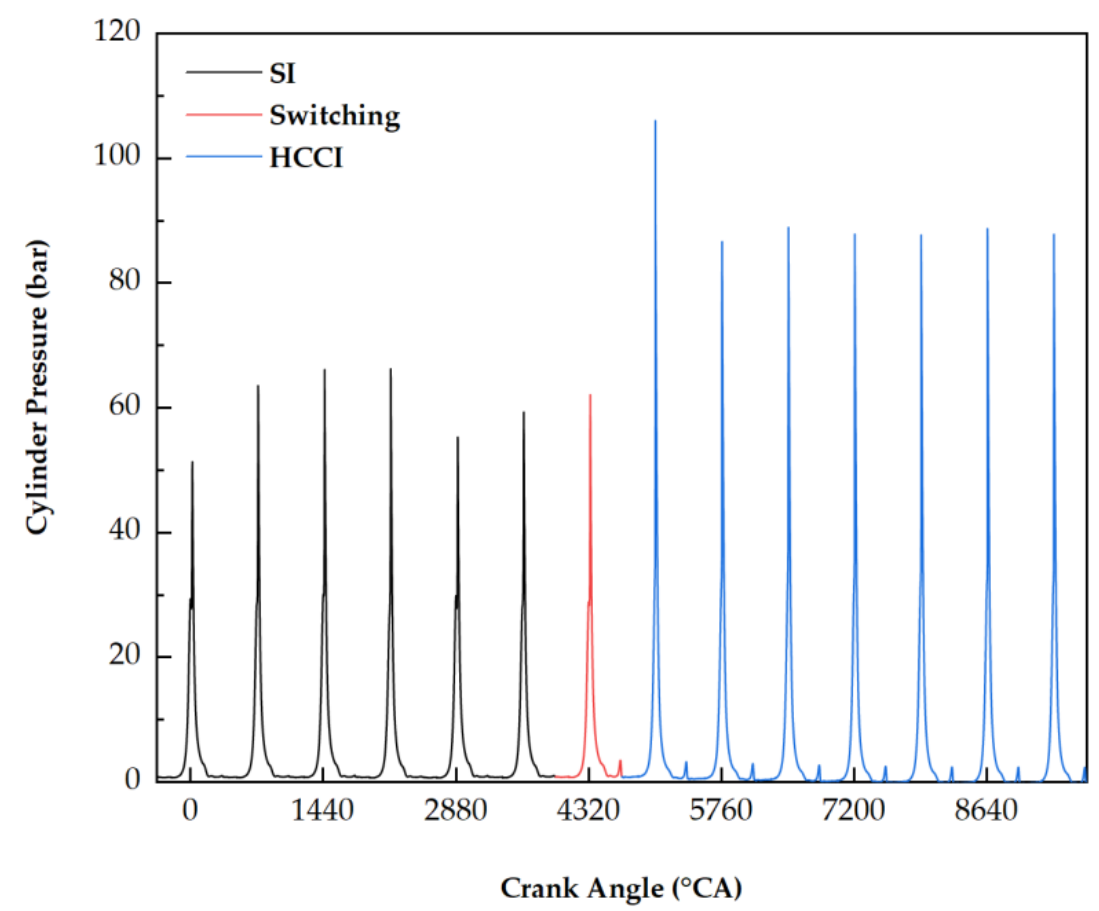

Figure 11. Cylinder pressure curve change during switching.

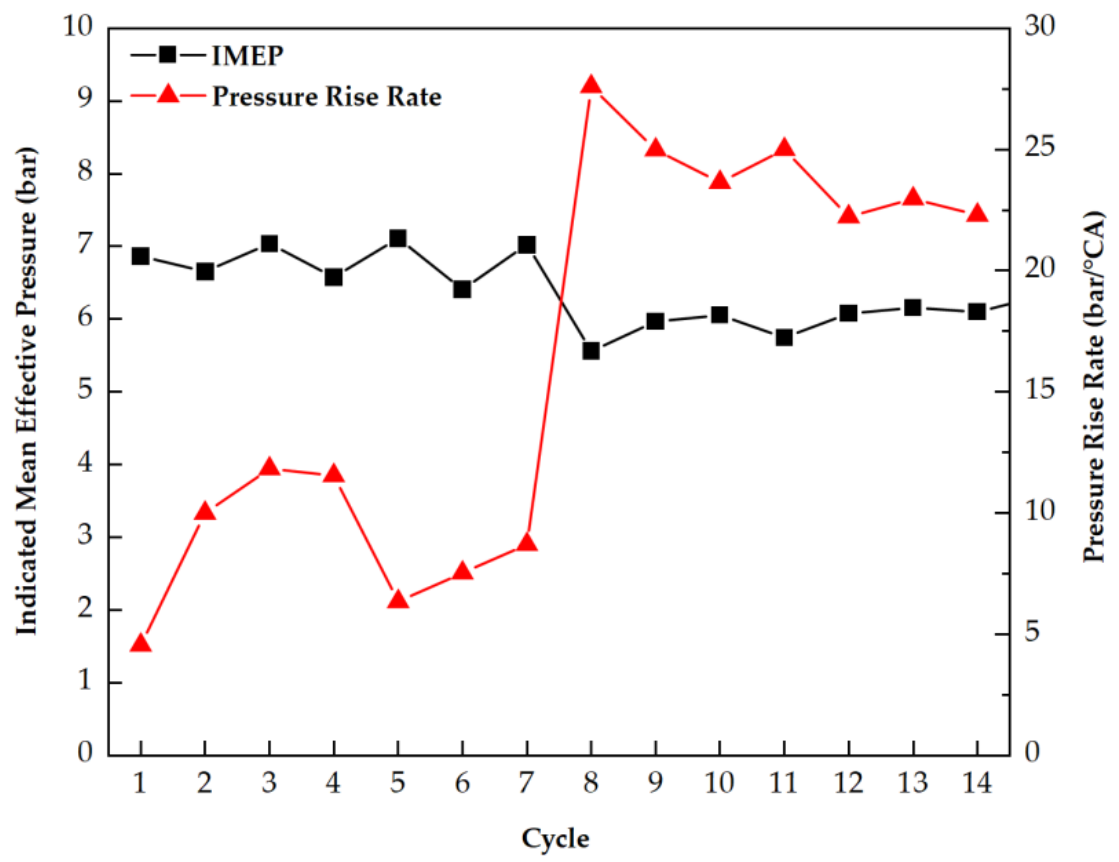

Figure 12. The IMEP and pressure rise rate changes during switching. 


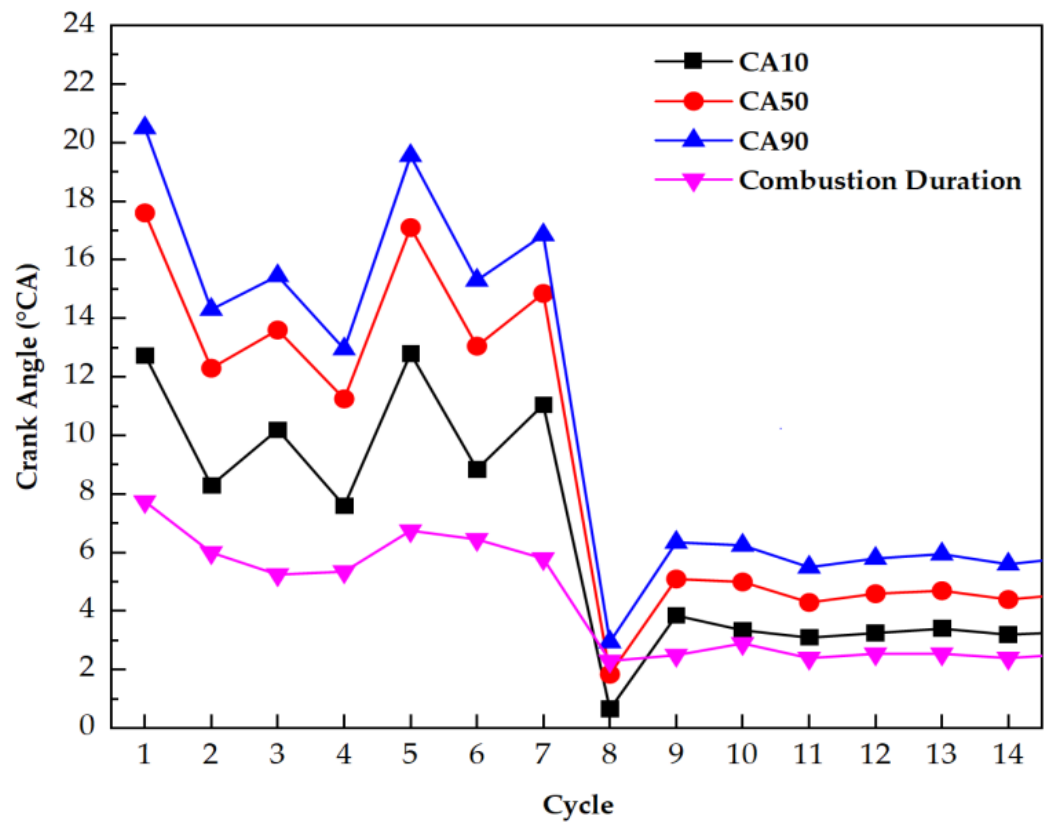

Figure 13. CA10, CA50, CA90 and Combustion Duration changes during switching.

\section{Conclusions}

This paper studies the possibility of HCCI combustion by the intake port EGR type VVA mechanism and studies the possibility of switching from SI to HCCI mode. In the steady state experiment and when the engine speed is $1000 \mathrm{rpm}$, if the MLEV is higher than $5.0 \mathrm{~mm}$ or lower than $1.5 \mathrm{~mm}$ and HCCI combustion cannot operate stably; when the MLEV is $4.5 \mathrm{~mm}$, the range of $\lambda$ is the largest (1 1.5) and, then, as the MLEV falls, the range of $\lambda$ becomes smaller. At $1.5 \mathrm{~mm}$ of the MLEV, the range of $\lambda$ is reduced to 1.0 1.3. The maximum value of the MLEV remains the same at the three engine speeds (1000 rpm, $1200 \mathrm{rpm}$ and $1400 \mathrm{rpm}$ ), which is $5.0 \mathrm{~mm}$. The minimum value of the MLEV gradually climbs as the engine speed increases, $1000 \mathrm{rpm}$ : $1.5 \mathrm{~mm}, 1200 \mathrm{rpm}$ : $2.0 \mathrm{~mm}, 1400 \mathrm{rpm}$ : $3.0 \mathrm{~mm}$.

With the increase of engine speed, the range of IMEP gradually shortens-3.53 6.31 bar (1000 rpm), 4.11 6.75 bar (1200 rpm) and 5.02 6.09 bar (1400 rpm)—which proves that the HCCI combustion loads of the intake port EGR are high and cannot be extended to low loads.

The cyclic variation of HCCI combustion basically climbs with the decrease of the MLEV and slightly jumps with the increase of the engine speed. At $1000 \mathrm{rpm}$, when the MLEV is $5.0 \mathrm{~mm}$; the cyclic variation range is $0.94 \% \sim 1.5 \%$. As the MLEV decreases to $1.5 \mathrm{~mm}$, the cycle variation range expands to $3.5 \% \sim 4.5 \%$. Taking the maximum value of the MLEV as an example, the cyclic variation range of $1000 \mathrm{rpm}$ is $0.94 \% \sim 1.5 \%, 1200 \mathrm{rpm}$ becomes $1.5 \% \sim 2.3 \%$ and $1400 \mathrm{rpm}$ expands to $2.0 \% \sim 2.5 \%$.

A set of combustion mode switching data is selected to show the response characteristics of the CDH-VVA mechanism. At $1000 \mathrm{rpm}$, when the IMEP of SI is $6.7 \mathrm{bar}$ and $\lambda$ is 1.2 , it switches to HCCI combustion after only one combustion cycle and the combustion switches to stable $\mathrm{HCCI}$ combustion after two combustion cycles, which proves that the $\mathrm{CDH}-\mathrm{VVA}$ mechanism responds quickly.

Through the study of the HCCI combustion characteristics of the CDH-VVA mechanism, it can be seen that only the exhaust valve lift and timing are changed, the intake valve remains unchanged, a high compression ratio is needed and HCCI combustion can only be achieved at medium and large loads. The HCCI combustion achieved by the above-mentioned method has a large pumping loss and compression negative work, which cannot ameliorate the thermal efficiency of the engine. However, the simultaneous adjustment of lift and timing realized by this mechanism enhances the response speed of valve 
adjustment and the switching between SI and HCCI modes is relatively rapid. Combining the above information, it is precisely because of the rapid response speed of the CDH-VVA mechanism, combined with future optimization to expand the HCCI combustion range, it is believed that the CDH-VVA mechanism has great potential in improving engine economy, power and emissions.

Author Contributions: Data curation, writing - original draft preparation, Y.W.; Conceptualization, methodology, validation, investigation, resources, J.D. and D.Q.; writing-review and editing, supervision, project administration, funding acquisition, L.H., Y.G. and Y.S.; validation, investigation, F.X. All authors have read and agreed to the published version of the manuscript.

Funding: This work is a key research and development plan supported by the Foundation of State Key Laboratory of Comprehensive Technology on Automobile Vibration and Noise \& Safety Control (Grant No. FAWSKL2020KFJJC1) and the National Natural Science Foundation of China (Grant No. 51876079).

Acknowledgments: This work is supported by the Foundation of State Key Laboratory of Comprehensive Technology on Automobile Vibration and Noise \& Safety Control (Grant No. FAWSKL2020KFJJC1) and the National Natural Science Foundation of China (Grant No. 51876079).

Conflicts of Interest: The authors declare no conflict of interest.

\section{Nomenclature}

\begin{tabular}{|c|c|}
\hline VVA & variable valve actuation \\
\hline $\mathrm{HCCI}$ & homogeneous charge compression ignition \\
\hline EGR & exhaust gas recirculation \\
\hline CDH-VVA & cam driven hydraulic variable valve actuation \\
\hline SI & spark ignition \\
\hline $\mathrm{CI}$ & compression ignition \\
\hline TPG & tappet piston group \\
\hline VPG & valve piston group \\
\hline HLCV & high-low check valve \\
\hline $\mathrm{TP}$ & tappet piston \\
\hline TPC & tappet piston cavity \\
\hline OWRV & one-way restrictor valve \\
\hline VPC & valve piston cavity \\
\hline VSP & valve spring preload \\
\hline VSBM & valve-seating buffer mechanism \\
\hline ITVRA & intake throttle valve rotation angle \\
\hline ETVRA & exhaust throttle valve rotation angle \\
\hline$\lambda$ & excess air coefficient \\
\hline IMEP & indicated mean effective pressure \\
\hline MLEV & maximum lift of the exhaust valve \\
\hline CA & crank angle \\
\hline CA10 & crank angle of $10 \%$ fuel burned \\
\hline CA50 & crank angle of $50 \%$ fuel burned \\
\hline CA90 & crank angle of $90 \%$ fuel burned \\
\hline Combustion Duration & crank angle of $10 \%-90 \%$ fuel burned \\
\hline BTDC & before top dead center \\
\hline
\end{tabular}

\section{References}

1. Joshi, A. Review of vehicle engine efficiency and emissions. SAE Int. J. Adv. Curr. Pract. Mobil. 2019, 1, 734-761.

2. Lyu, M.; Bao, X.F.; Zhu, R.C.; Matthews, R. State-of-the-art outlook for light-duty vehicle emission control stand-ards and technologies in China. Clean Technol. Environ. Policy 2020, 22, 757-771. [CrossRef]

3. Pan, S.; Wang, J.; Huang, Z. Development of 1.5L Dedicated Hybrid Engine with 42.6\% Brake Thermal Efficiency. SAE Int. J. Engines 2021. [CrossRef]

4. De Bellis, V. Performance optimization of a spark-ignition turbocharged VVA engine under knock limited oper-ation. Appl. Energy 2016, 164, 162-174. [CrossRef] 
5. Teodosio, L.; De Bellis, V.; Bozza, F. Combined Effects of Valve Strategies, Compression Ratio, Water Injection, and Cooled EGR on the Fuel Consumption of a Small Turbocharged VVA Spark-Ignition Engine. SAE Int. J. Engines 2018, 11, 643-656. [CrossRef]

6. Onishi, S.; Jo, S.H.; Shoda, K.; Jo, P.D.; Kato, S. Active Thermo-Atmosphere Combustion (ATAC)—A New Combustion Process for Internal Combustion Engines. SAE Int. 1979, 88, 1851-1860.

7. Gentili, R.; Frigo, S.; Tognotti, L.; Habert, P.; Lavy, J. Experimental Study on ATAC (Active Thermo-Atmosphere Combustion) in a Two-Stroke Gasoline Engine. SAE Int. 1997, 106, 638-644. [CrossRef]

8. Noguchi, M.; Tanaka, Y.; Tanaka, T.; Takeuchi, Y. A Study on Gasoline Engine Combustion by Observation of In-termediate Reactive Products during Combustion. SAE Int. 1979, 88, 2816-2828.

9. Ishibashi, Y.; Asai, M. Improving the Exhaust Emissions of Two-Stroke Engines by Applying the Activated Radical Combustion. SAE Int. 1996, 105, 982-992.

10. Gowthaman, S.; Sathiyagnanam, A.P. Analysis the optimum inlet air temperature for controlling homogeneous charge compression ignition (HCCI) engine. AEJ -Alex. Eng. J. 2017, 57, 2209-2214. [CrossRef]

11. Thring, R.H. Homogeneous-Charge Compression-Ignition (HCCI) Engines; SAE Technical Paper 892068; SAE: Warrendale, PA, USA, 1989. [CrossRef]

12. Christensen, M.; Johansson, B.; Einewall, P. Homogeneous Charge Compression Ignition (HCCI) Using Isooctane, Ethanol and Natural Gas-A Comparison with Spark Ignition Operation. SAE Int. 1997, 106, 1104-1114. [CrossRef]

13. Willand, J.; Nieberding, R.-G.; Vent, G.; Enderle, C. The Knocking Syndrome-Its Cure and Its Potential. SAE Int. 1998, 107, 1122-1129. [CrossRef]

14. Kontarakis, G.; Collings, N.; Ma, T. Demonstration of HCCI Using a Single Cylinder Four-stroke SI Engine with Modified Valve Timing. SAE Int. 2000, 109, 2057-2067. [CrossRef]

15. Li, J.; Zhao, H.; Ladommatos, N.; Ma, T. Research and Development of Controlled Auto-Ignition (CAI) Combustion in a 4-Stroke Multi-Cylinder Gasoline Engine. SAE Int. 2001, 110, 2114-2122. [CrossRef]

16. Persson, H.W.; Pfeiffer, R.A.; Hultqvist, A.; Johansson, B.; Ström, H. Cylinder-to-Cylinder and Cycle-to-Cycle Variations at HCCI Operation with Trapped Residuals; SAE Technical Paper 2005-01-0130; SAE: Warrendale, PA, USA, 2005. [CrossRef]

17. Takazawa, M.; Komura, K.; Kitamura, T. Transient Control Technology of Spark Assisted HCCI; SAE Technical Paper 2015-01-0880; SAE: Warrendale, PA, USA, 2015. [CrossRef]

18. Cairns, A.; Blaxill, H. The Effects of Combined Internal and External Exhaust Gas Recirculation on Gasoline Controlled Auto-Ignition; SAE Technical Paper 2005-01-0133; SAE: Warrendale, PA, USA, 2005. [CrossRef]

19. Zhang, Y.; Xie, H.; Zhou, N.; Chen, T.; Zhao, H. Study of SI-HCCI-SI Transition on a Port Fuel Injection Engine Equipped with 4VVAS; SAE Technical Paper 2007-01-0199; SAE: Warrendale, PA, USA, 2007. [CrossRef]

20. Nier, T.; Kulzer, A.; Karrelmeyer, R. Analysis of the Combustion Mode Switch Between SI and Gasoline HCCI; SAE Technical Paper 2012-01-1105; SAE: Warrendale, PA, USA, 2012. [CrossRef]

21. Liu, Y.; Li, L.; Lu, H.; Schmitt, S.; Deng, J.; Rao, L. SI/HCCI Mode Switching Optimization in a Gasoline Direct Injection Engine Employing Dual Univalve System. J. Eng. Gas Turbines Power 2019, 141, 031001.1-031001.8. [CrossRef]

22. Milovanovic, N.; Dave, B.; Gedge, S.; Turner, J.W.G. Cam Profile Switching (CPS) and Phasing Strategy vs Fully Variable Valve Train (FVVT) Strategy for Transitions between Spark Ignition and Controlled Auto Ignition Modes. In Proceedings of the 2005 SAE World Congress, Detroit, MI, USA, 11-14 April 2005; 2005. [CrossRef]

23. Tian, G.-H.; Wang, Z.; Ge, Q.-Q.; Wang, J.-X.; Shuai, S.-J. Study of SI-HCCI-SI mode switching in a GDI engine. Trans. CSICE 2007, 25, 229-234.

24. Calam, A.; Aydoğan, B.; Halis, S. The comparison of combustion, engine performance and emission characteristics of ethanol, methanol, fusel oil, butanol, isopropanol and naphtha with n-heptane blends on HCCI engine. Fuel 2020, 266, 117071. [CrossRef]

25. Verma, S.K.; Gaur, S.; Akram, T.; Samsher Kumar, A. Performance characteristic of HCCI engine for different fuels. Mater. Today: Proc. 2021, 47, 6030-6034. [CrossRef]

26. Asghari, M.; Saray, R.K.; Neshat, E. Mathematical Modeling of Knocking Combustion and Created Pressure In-homogeneity Inside the Combustion Chamber in HCCI Engines Via Multi Zone Model. Flow Turbul. Combust. 2020, 105, 213-236. [CrossRef]

27. D'Amato, M.; Viggiano, A.; Magi, V. On the Turbulence-Chemistry Interaction of an HCCI Combustion Engine. Energies 2020, 13, 5876. [CrossRef]

28. Zhou, Y.; Lawler, B. Validation of Kinetic Mechanisms against Various Ignition Delay Data and the Development of Ignition Delay Correlations for Ethanol, Natural Gas, and Primary Reference Fuel Blends under Homogeneous Charge Compression Ignition Conditions. SAE Int. J. Engines 2021, 15. [CrossRef]

29. Hikita, T.; Mizuno, S.; Fujii, T.; Yamasaki, Y.; Hayashi, T.; Kaneko, S. Study on Model-Based Control for HCCI Engine. IFACPapersOnLine 2018, 51, 290-296. [CrossRef]

30. Nam, Y.; Kim, J.; Bahk, C.; Jang, I.; Song, H.H.; Lee, N. Modeling, Estimation, and Control of HCCI Engine with In-Cylinder Pressure Sensing. J. Dyn. Syst. Meas. Control. 2018, 140, 061015. [CrossRef]

31. Zhu, D.; Deng, J.; Wang, S.; Zhang, H.; Wu, Z.; Andert, J.; Li, L. Cycle resolved control for HCCI engine load range ex-pansion by combining ion current and pressure sensor. Proc. Combust. Inst. 2021, 38, 5685-5694. [CrossRef]

32. Jin, Z.; Hong, W.; You, T.; Su, Y.; Li, X.; Xie, F. Effect of Multi-Factor Coupling on the Movement Characteristics of the Hydraulic Variable Valve Actuation. Energies 2020, 13, 2870. [CrossRef] 
33. Wolters, P.; Salber, W.; Geiger, J.; Duesmann, M.; Dilthey, J. Controlled Auto Ignition Combustion Process with an Electromechanical Valve Train. SAE Int. 2003, 112, 160-168. [CrossRef]

34. Santoso, H.; Matthews, J.; Cheng, W.K. Managing SI/HCCI Dual-Mode Engine Operation; SAE Technical Paper 2005-01-0162; SAE: Warrendale, PA, USA, 2005. [CrossRef]

35. Zhao, H.; Peng, Z.; Williams, J.; Ladommatos, N. Understanding the Effects of Recycled Burnt Gases on the Con-trolled Autoignition (CAI) Combustion in Four-Stroke Gasoline Engines. SAE Int. 2001, 110, 2100-2113.

36. Liu, F.-F.; Wang, Y.-K.; Li, H.; Gao, F.-J.; Huang, W.-J.; Guo, Y.-N. Performances of electro-hydraulic valve train and application. Trans. CSICE 2011, 29, 54-60. 